\title{
First record of Charadrius melodus Ord (Aves Charadriiformes) in Brazil
}

\author{
Severino Mendes de Azevedo Júnior ${ }^{1,2}$, Maria Eduarda de Larrazábal ${ }^{2} \&$ Oldair Pena ${ }^{3}$
}

${ }^{1}$ Departamento de Biologia, Universidade Federal Rural de Pernambuco. Rua Dom Manuel de Medeiros, Dois Irmãos, 52171-900 Recife, Pernambuco, Brasil.E-mail: smaj@ufpe.br

2 Programa de Pós-graduação em Biologia Animal, Departamento de Zoologia, Universidade Federal de Pernambuco. Avenida Prof. Moraes Rego 1235, Cidade Universitária, 50670-420 Recife, Pernambuco, Brasil. E-mail: mells@ufpe.br

3 Salina Diamante Branco, Gerência de Meio Ambiente. Avenida Romualdo Galvão 1703, sala 301 a 310, Lagoa Nova, 59022-100 Natal, Rio Grande do Norte, Brasil.

\begin{abstract}
Charadrius melodus Ord, 1824 were captured at Diamante Branco saline, at Galinhos municipal district in Rio Grande do Norte, at the Northeast coast of Brazil. Four individuals were captured in October and two in December. All of them were in adult phase, showing the intermediary plumage with moults of the outline feathers. One individual captured in October showed moult for the first primary pinion and other captured also in October showed moult in the second pair of rectrices. The captures of $C$. melodus in Rio Grande do Norte consist in the first record of the species for Brazil.
\end{abstract}

KEY WORDS. Conservation, monitoring, saline, shorebirds.

The Piping Plover, Charadrius melodus Ord, 1824, is an shorebirds species of Central America and Eastern North America, showing two populations: a coastal and other in the Great Lakes Region. Voous (1983) reported the species to South America. It uses sandy beaches environments, areas traditionally occupied by man. It carries through reproduction from May to August in New Scotland, USA and is present throughout the year in North Carolina, USA. It prefers beaches with little vegetation for nesting and raising their nestlings (CAIrNs 1982). Shows declining population in the Great Lakes Region and Atlantic coast. The identification is made mainly by the color of the leg feathers and the shining orange beak base, close to red (CaIRns 1982, Russel 1983, HaYMAN et al. 1986, Brown et al. 2001).

Through a monitoring program of shorebirds involving census, captures and re-captures in sandy habitats of Diamante Branco saline, it was possible to make this record.

\section{MATERIAL AND METHODS}

The Diamante Branco saline is situated in Galinhos municipal district, North coast of Rio Grande do Norte state, at Northeast coast of Brazil, under the geografical coordinates of $05^{\circ} 05^{\prime} 26^{\prime \prime} \mathrm{S}$ and $36^{\circ} 16^{\prime} 31^{\prime \prime} \mathrm{W}$. The North coast of Rio Grande do Norte consists in the country's most important saliniferous area (Fig. 1). The Diamante Branco saline presents an area of circa 2500 ha of tanks for salt production (evaporators and crystallizers) and 2800 hectares of natural areas, specially the sandy beaches of Thomas and Galinhos rivers, estuary beaches, dunes, mangrove areas and others. The creeping vegetation formed basically by Sesuvium portulacastrum, (L.) L. (Aizoaceae), Salicornia gaudichaudiana Moq. (Chenopodiaceae), Batis maritima L. (Bataceae), and Phylloxerus portulacoides St. Hil. (Amarantaceae) marks salty environments. It constitutes areas of winter season for Charadriidae and Scolopacidae during boreal migration and reproduction sites for Charadrius collaris Vieillot, 1818; C. wilsonia Ord, 1814 e Himantopus himantopus (Müller, 1776).

Shorebirds were captured using mist nets set on the sandy areas of the evaporators of Diamante Branco saline in October and December of 2000. The captured specimens were identified, plumage, moults, age and body mass were verified and biometry of beak, wings, tail and ankle were taken. The sexing took place during taxidermy.

\section{RESULTS AND DISCUSSION}

Six male specimens of Charadrius melodus were captured: four in October $27^{\text {th }}$ and two in December $7^{\text {th }}$ of 2000 . The specimens captured in October showed the intermediary plumage (feathers of reproductive and non-reproductive plumage)

Revista Brasileira de Zoologia 20 (3): 559-560, setembro 2003 


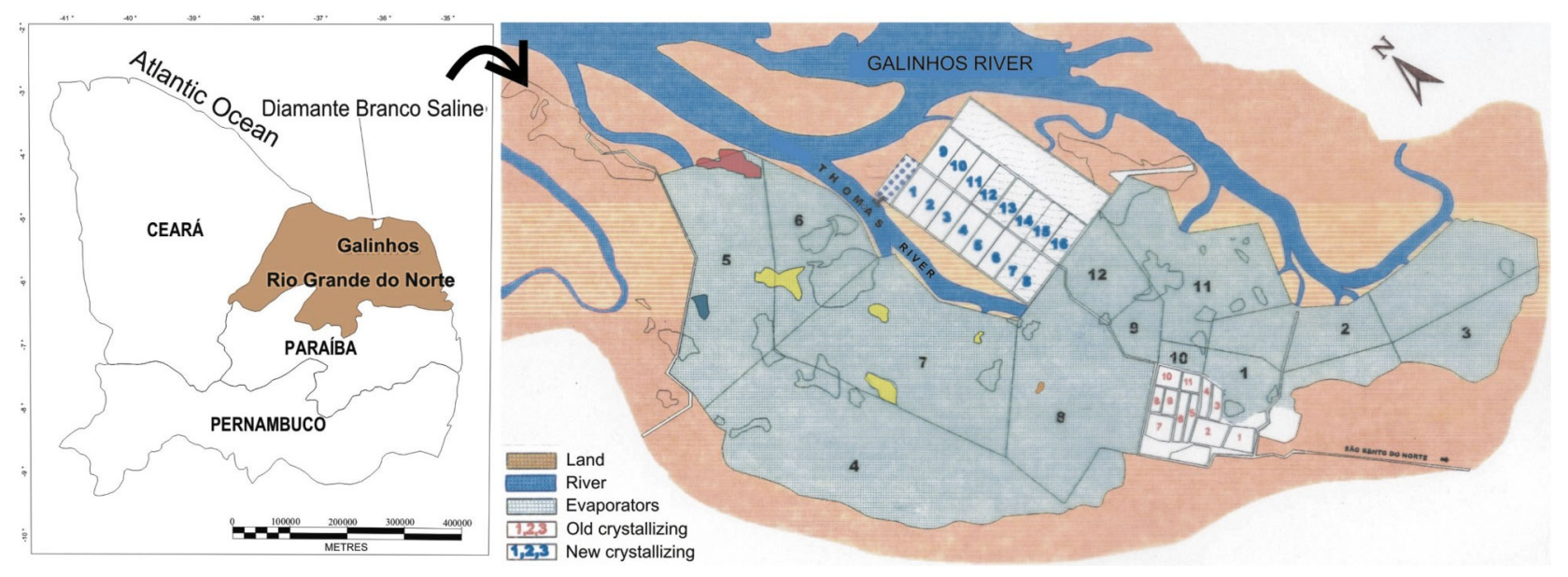

Fig. 1. Map of Diamante Branco saline outstanding the evaporators where the Charadrius melodus sample were collected.

making the outlike feather moults, specially in the dorsum. Three specimens did not show pinion moults. One specimen captured in October showed pinion moult for the first primary. As to the rectrices, one specimen in October was changing the second pair and the rest did not show moults. Both specimens captured in December showed the intermediary plumage without pinion or rectrix moults and only one of them was changing the outline feathers in the head, dorsum and venter segments. Table I shows the body mass and the data collected in the biometry of captured individuals.

The capture of C. melodus at Rio Grande do Norte coast consists in the southeastern most record for the species and also the first record for Brazil. This species probably occur in other areas of brazilian coast and has been observed and counted in census as Charadrius semipalmatus Bonaparte, 1825 since it is hard to distinguish between them with binoculars or spectacles. However, during capture and handling of the specimen it can be observed the orange, almost red legs and base of the beak, the same color membrane around the eyes and the white spot at the superior area of the tail, wich characterize the species. The captures made at Rio Grande do Norte can indicate a migration until now unknown for the species in Brazil. The need of studies in other sites of Brazilian coast to promote its conservation is therefore indicated.

\section{ACKNOWLEDGEMENTS}

We would like to thanks the Federal and Federal Rural Universities of Pernambuco (UFPE, UFRPE). In special to the Diamante Branco saline's administration for the support to the present work and to Professor Antonio Rossano of UFPE for the review of the text.
Table I. Charadrius melodus captured in October 23rd (numbers 1 to 4) and in December 7th of 2000 (numbers 5 and 6), in Diamante Branco saline, Galinhos, Rio Grande do Norte, Brazil.

\begin{tabular}{clccccc}
\hline Number & Month & $\begin{array}{c}\text { Body } \\
\text { Mass }(\mathrm{g})\end{array}$ & $\begin{array}{c}\text { Wing } \\
(\mathrm{mm})\end{array}$ & $\begin{array}{c}\text { Tail } \\
(\mathrm{mm})\end{array}$ & $\begin{array}{c}\text { Ankle } \\
(\mathrm{mm})\end{array}$ & $\begin{array}{c}\text { Beak } \\
(\mathrm{mm})\end{array}$ \\
\hline 1 & October & 40 & 122 & 54 & 23,0 & 13,6 \\
2 & October & 41 & 123 & 53 & 23,6 & 13,0 \\
3 & October & 41 & 122 & 52 & 22,8 & 13,4 \\
4 & October & 41 & 122 & 53 & 22,4 & 13,0 \\
5 & December & 38 & 126 & 54 & 23,4 & 13,8 \\
6 & December & 42 & 127 & 55 & 23,6 & 13,6 \\
\hline
\end{tabular}

\section{REFERENCES}

Brown, S.; C. Hickey; B. Harrington \& R. Gill. 2001. The U.S. Shorebird Conservation Plan. Manomet, Manomet Center for Conservation Sciences, 61p.

CAIRNs, W.E. 1982. Biology and behaviour of breeding Piping Plover. Wilson Bulletin, Manhattan, 94: 531-545.

Hayman, P.; J. Marchant \& T. Prater. 1988. Shorebirds: an identification guide. Boston, Houghton Mifflin Company, $412 \mathrm{p}$.

Russel JR., R.P. 1983. The Piping Plover in the Great Lakes Region. American Birds, Washington, D.C., 37: 951-955.

Voous, K.H. 1983. Birds of the Netherlands Antilles. Curaçao, De Walburg Press, 327p.

Received in 18.II.2003; accepted in 19.VIII.2003.

Revista Brasileira de Zoologia 20 (3): 559-560, setembro 2003 